\title{
Response of Cotton Varieties Against Insect Pests and Cotton Leaf Curl Disease
}

\author{
Muhammad Naveed *, Rashid Ahmed Khan, Khalid Pervaiz Akhtar, Mureed Hussain
}

Plant Protection Division, Nuclear Institute for Agriculture and Biology (NLAB), P.O. Box 128, Jhang Road, Faisalabad, Pakistan.

\begin{abstract}
Cotton is one of the major cash crops of Pakistan. It suffers from severe yield losses because of various insect pests and diseases. Whiteflies and jassids are regarded as the key pests of cotton. Beside these, pink bollworm is also one of major devastators of this crop. Present study was conducted to evaluate the performance of Bt and non Bt varieties against these three major pests of cotton. Data were taken from upper, middle and lower leaves in case of sucking pests and for pink bollworm 5 plants were selected for determining its percent infestation. Data for CLCuD was computed using percent disease index (PDI). The results showed that non Bt varieties were heavily attacked by whiteflies with population above economic threshold level (ETL). Maximum mean population of 5.67 was recorded on NIAB-Karishma. Cotton jassid population was above ETL in all the varieties under study, with a maximum mean population of 1.80 on IR-NIAB-824. Moreover, population of pink bollworm was higher on Bt varieties as compared to the non Bt varieties with maximum mean percent infestation of $51.34 \%$ on Lalazar. The highest yield of $826 \mathrm{~kg} / \mathrm{acre}$ was observed in NIAB-Karishma. All the tested varieties were highly susceptible to cotton leaf curl disease and there was no significant correlation of whitefly levels with percent disease index.
\end{abstract}

Keywords: Bt and non Bt cotton varieties, Whitefly, Cotton jassid, Pink bollworm, Infestation, CLCuD, Cotton yield.

Editor | Muhammad Nauman Zahid, Quality Operations Laboratory, University of Veterinary and Animal Sciences, Lahore, Pakistan.

Received | November 29, 2018 Accepted | February 22, 2019; Published | April 15, 2020

*Correspondence | Muhammad Naveed, Plant Protection Division, Nuclear Institute for Agriculture \& Biology (NIAB), P.O. Box 128, Jhang Road, Faisalabad, Pakistan; Email: naveedtjam@gmail.com

Citation | Naveed M, Khan RA, Akhtar KP, Hussain M (2020). Response of cotton varieties against insect pests and cotton leaf curl disease. S. Asian J. Life Sci. $8(1): 1-5$.

DOI | http://dx.doi.org/10.17582/journal.sajls/2020/8.1.1.5

ISSN | 2311-0589

Copyright (C) 2019 Naveed et al. This is an open access article distributed under the Creative Commons Attribution License, which permits unrestricted use, distribution, and reproduction in any medium, provided the original work is properly cited.

\section{INTRODUCTION}

C otton is an important asset towards the economy of Pakistan, as it solely contributes a total of $1.5 \%$ in the overall economy of the country (Anonymous, 2015). It has exceptionally high demand in textile industry as it provides the major raw material i.e. fiber, to the industry. Pakistan is the $4^{\text {th }}$ largest producer of cotton after China, India and USA. However, its production in the country is threatened by a number of insect pests and diseases. Cotton pests are categorized into sucking and chewing pest complex. They averagely cause $5-10 \%$ loss in cotton yield, but in extreme cases the damage can be as high as $40-50 \%$ (Naqvi, 1976). Cotton whitefly (Bemisia tabaci Gennadius) is one of the key pests that infests cotton crop. Its population, prevail throughout the crop season, however it is observed in huge proportion during the vegetative growth of the plant. It considerably reduces the formation of the boll by sucking the cell sap Ahmad et al. (2001). Whitefly is also known to be the sole vector of devastating cotton leaf curl virus disease Nelson et al. (1998). Cotton jassid (Amarsca devastans Distant), is also an important pest of cotton. It is extremely damaging to the crop and even a single jassid requires its management. It causes severe losses to cotton by sucking cell sap and also by inducing toxin which may cause almost $5 \%$ reduction in the crop yield (Bhat, 1986).

Chewing pests damage leaves and bolls of the cotton. Introduction of Bt varieties having Bt toxin gene has significantly reduced infestation of these pests. However, the 
Table 1: Disease scale for rating of cotton leaf curl disease (CLCuD).

\begin{tabular}{|c|c|c|c|c|}
\hline $\begin{array}{l}\text { Disease } \\
\text { rating }\end{array}$ & Symptoms & $\begin{array}{l}\text { Severity } \\
\text { index }\end{array}$ & $\begin{array}{l}\text { Percent Disease } \\
\text { index }\end{array}$ & Disease response \\
\hline 0 & $\begin{array}{l}\text { Complete absence of symptoms and virus cannot be de- } \\
\text { tected in plant tissues using molecular techniques. }\end{array}$ & 0 & 0 & Highly resistant \\
\hline 1 & $\begin{array}{l}\text { Complete absence of symptoms but virus can be detected } \\
\text { in plant tissues using molecular techniques. } \\
\text { OR } \\
\text { Thickening of few small scattered veins or only presence of } \\
\text { leaf enations on one or few leaves of a plant (all observa- } \\
\text { tions should be done carefully). }\end{array}$ & $0.1-1.4$ & $0.1-10$ & Resistant \\
\hline 2 & $\begin{array}{l}\text { Thickening of small group of veins, no leaf curling, no } \\
\text { reduction in leaf size and boll setting. }\end{array}$ & $1.5-2.4$ & $10.1-20$ & $\begin{array}{l}\text { Moderately resist- } \\
\text { ant }\end{array}$ \\
\hline 3 & $\begin{array}{l}\text { Thickening of all veins, minor leaf curling \& deformity of } \\
\text { internode with minor reduction in leaf size but no reduc- } \\
\text { tion in boll setting. }\end{array}$ & $2.5-3.4$ & $20.1-30$ & Tolerant \\
\hline 4 & $\begin{array}{l}\text { Severe vein thickening, moderate leaf curling followed by } \\
\text { minor deformity of internodes and minor reduction in leaf } \\
\text { size and boll setting. }\end{array}$ & $3.5-4.4$ & $30.1-40$ & $\begin{array}{l}\text { Moderately suscep- } \\
\text { tible }\end{array}$ \\
\hline 5 & $\begin{array}{l}\text { Severe vein thickening, moderate leaf curling \& deformity } \\
\text { of internodes with moderate reduction in leaf size and boll } \\
\text { setting followed by moderate stunting. }\end{array}$ & $4.5-5.4$ & $40.1-50$ & Susceptible \\
\hline 6 & $\begin{array}{l}\text { Severe vein thickening, leaf curling, reduction in leaf size, } \\
\text { deformed internodes and stunting of the plant with no or } \\
\text { few boll setting. }\end{array}$ & $5.5-6.0$ & 50 & Highly susceptible \\
\hline
\end{tabular}

pests have attained resistance against $\mathrm{Bt}$ toxin gene over the time (Tabashnik, 1994; Gould, 1998), and the highest amount of resistance is shown by Pink bollworm (Pictinophora gossypiella, Saunders) (Wu and Guo, 2005). Its resistance against the toxin gene keeps increasing every year, Tabashnik et al. (2012) thus presenting an alarming threat to the cotton industry throughout the world. There is an urgent need to focus continuously on population of pink bollworm to avoid its infestation. Considering the importance of the mentioned issues of cotton crop, present study was conducted to monitor the population of cotton whitefly, cotton jassid, pink bollworm and response to $\mathrm{CLCuD}$ in different $\mathrm{Bt}$ and non $\mathrm{Bt}$ cotton varieties.

\section{MATERIALS AND METHODS}

Six Bt (Lalazar, IR-NIBGE-1524, NIAB-Bt-1, IRNIBGE-3, IR-NIAB-824 \& Bt-114) and five non Bt (NIAB-86, N-KARISHMA, NIAB-852, NIAB-777 \& NIAB-846) varieties were sown at Nuclear Institute for Agriculture \& Biology (NIAB), Faisalabad in three replicates following Randomized Complete Block Design (RCBD). Each replicate was cultivated in an area of $25 \times 105 \mathrm{ft}^{2}$, separated by $2.5 \mathrm{ft}$ path.

Population of cotton whiteflies (Bemesia tabasi Gennadius) and jassids (Amarsca devastans Distant) were monitored on weekly basis starting from May, until July, 2015. Data were recorded from upper, middle and lower leaves of five ran- domly selected plants in each experimental unit. Moreover, later in the season during the months of August-September, the population of pink bollworm was monitored by observing infested bolls to calculate the percent infestation. The bolls were checked by pressing them with fingers; and were cracked if found soft in order to determine the rate of infestation. The damaged bolls or those having the pest inside, were considered as infested. Data for CLCuD were recorded following the rating system described in Table-1 to calculate percent disease index (PDI) and response of varieties as suggested by Akhtar et al. (2010).

Data were analyzed by two-way Analysis of Variance (ANOVA) and means were distinguished by Tuckey's multiple range test at $\alpha=0.05$ level of significance using statistical software (Statistix 8.1, Tallahassee, Florida, USA).

\section{RESULTS AND DISCUSSION}

\section{Field Monitoring of Insects Pests}

The maximum infestation level of cotton whiteflies was recorded as 5.67, 5.57, and 5.32, on NIAB-Karishma, IR-NIBGE-1524, and NIAB-846, respectively. Whereas, NIAB-852, NIAB-86, NIAB-777, IR-NIAB-824, IR-NIBGE-3, Lalazar and NIAB-Bt-1, showed an infestation of 5.27, 5.14, 4.74, 4.64, 3.94, 3.86, and 3.38, respectively. Bt-114 was observed to have the minimum mean whitefly population of 2.26 . These results contradict with 
the results of Jeyakumar et al. (2008) who reported that whitefly population was more on Bt varieties than on the non Bt. The population of whitefly on certain Bt varieties may be low due to certain morphological factor such as less gossypole contents and thickness of lamina as it have positive correlation with whitefly population and hair length and thickness of hairs having negative correlation with whitefly population $\mathrm{Zia}$ et al. (2011). IR-NIAB-824 was found to be the most susceptible variety against cotton jassids followed by IR-NIBGE-3, NIAB-777, IR-NIBGE-1524, Lalazar, NIAB-846, Bt-114, NIAB-852 and NIAB-Bt-1 with average jassid population of $1.80,1.75$, $1.63,1.53,1.49,1.49,1.37,1.35$ and 1.31 , respectively. Minimum population of jassids was recorded on NIAB-Karishma (1.14), and NIAB-86 (1.15). However, interestingly, the jassid population remained above economic threshold level (ETL) in all varieties (Figure 2). These findings are in accordance with the results of (Arshad and Suhail, 2010) who reported no significant difference between $\mathrm{Bt}$ and non $\mathrm{Bt}$ varieties against jassid infestation.

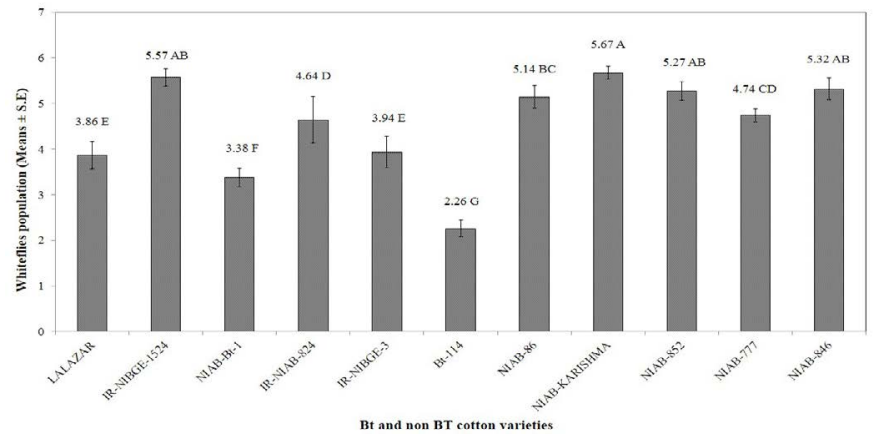

Figure 1: Mean infestation of cotton whiteflies on different Bt and non Bt cotton varieties. Means followed by the same letter in the same category are not significantly different at $\mathrm{P} \leq 0.05$

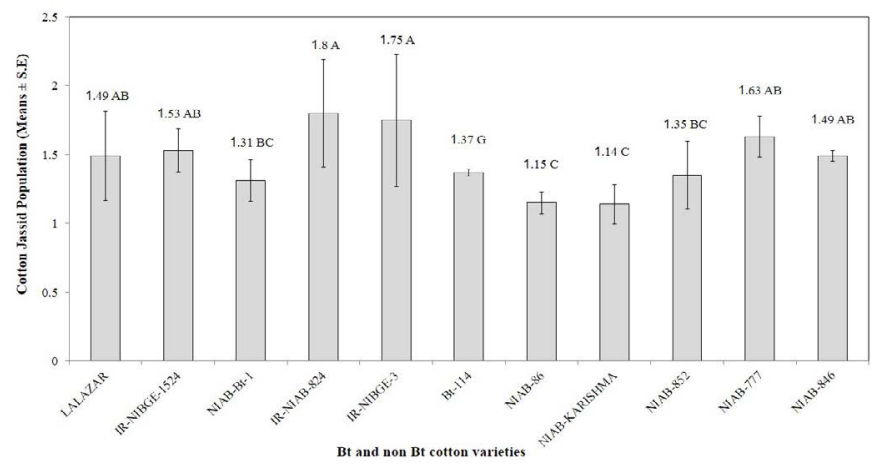

Figure 2: Mean infestation of cotton jassid on different Bt and non Bt cotton varieties. Means followed by the same letter in the same category are not significantly different at $\mathrm{P} \leq 0.05$

All the tested varieties were variably infested by pink bollworm. Maximum damage was observed in Bt variety $\mathrm{La}^{-}$ lazar (51.34\%). Mean pink bollworm infestation was recorded to be 42.76, 41.87,38.78,38.54,35.49, 34.91, 32.86, $28.62,26.72$ and $24.18 \%$ on IR-NIBGE-1524, IR-NIAB-824, NIAB-846, IR-NIBGE-3, NIAB- Bt-1, NIAB777, NIAB-852, Bt-114, NIAB-86 and NIAB-Karishma, respectively (Figure 3). Similar results were also reported by Tabashnik et al. (2012), who observed resistance in pink and American bollworm in different Bt cotton varieties. The results we obtained, could have been an outcome of ecological factors, or acquired resistance in pink bollworm. The results of the study contradict with the findings of Wan et al. (2004), who demonstrated that Bt varieties were less damaged by pink bollworm than conventional non $\mathrm{Bt}$ varieties.

There were significant differences regarding yield among all the tested varieties. NIAB-Karishma was found to be the most productive followed by IR-NIBGE-3, IR-NIBGE-1524, NIAB-86 with an average yield of 825,720 , 582 and $542 \mathrm{~kg} / \mathrm{acre}$, respectively. The yield of NIAB-Bt-1 (483 kg/acre), NIAB-777 (481 kg/acre) and NIAB-852 (474 kg/acre) were statistically similar. Minimum yield of $346 \mathrm{~kg} /$ acre was recorded for IR-NIAB-824 (Figure 4).

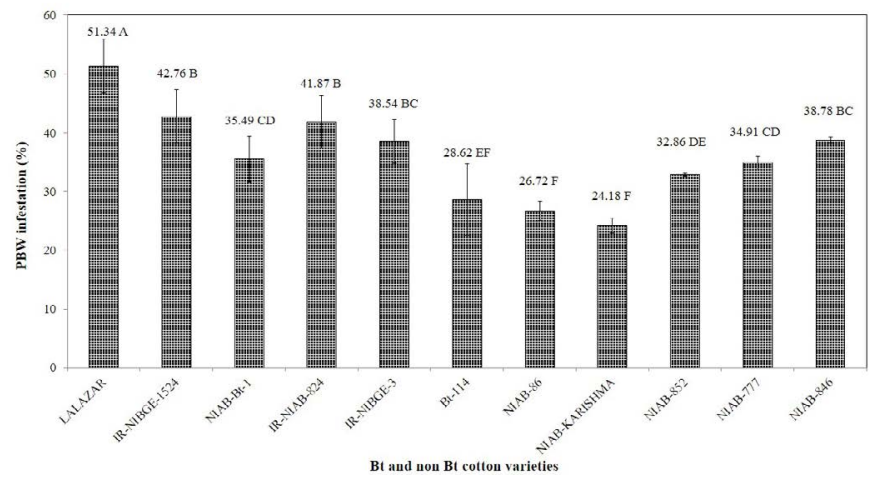

Figure 3: Percent infestation of PBW on different Bt and non Bt cotton varieties. Means followed by the same letter in the same category are not significantly different at $\mathrm{P} \leq 0.05$

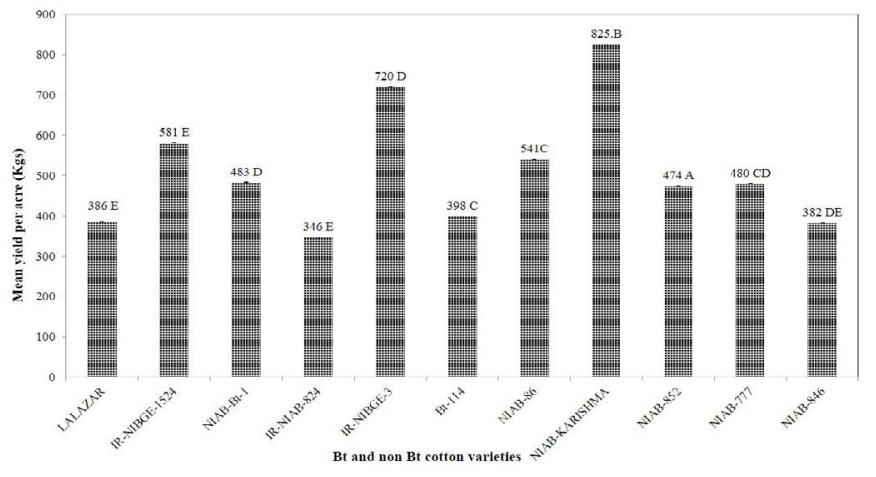

Figure 4: Yield per acre (Kgs) in different $\mathrm{Bt}$ and non Bt cotton varieties. Means followed by the same letter in the same category are not significantly different at $\mathrm{P} \leq 0.05$. 
$\overline{\mathrm{CLCuV}}$ vector whiteflies were observed to appear in low densities just after the emergence of seedlings. The whitefly population continued building up during the active growth of the crop, although their population fluctuated greatly during the whole period of the study. It was seen that none of the tested varieties was disease free (Figure 5). All varieties were infected systemically with virus and rated as highly susceptible. However, there were wide variations in percent disease index (PDI) ranging from 63 to $98 \%$ to $\mathrm{CLCuD}$ among the examined 11 varieties. The differences recorded for PDI were statistically significant. It was evident from



Figure 5: Occurrence of $\mathrm{CLCuV}$ in different $\mathrm{Bt}$ and non $\mathrm{Bt}$ cotton varieties. Means followed by the same letter in the same category are not significantly different at $\mathrm{P} \leq 0.05$.

LSD comparison that intensity of CLCuD was less in non Bt NIAB-Karishma and NIAB-846 (63) as compared to the Bt variety IR-NIAB 824 (98\%). Disease symptoms were observed to develop after 43 days of germination in all the tested varieties. Severe symptoms started with a minor vein thickening of young leaves, and gradually progressed to severe vein thickening, leaf curling, reduction in leaf size with "enations" of different types and sizes, deformation of internodes, eventually culminating in severe stunting of the plants with no or few bolls. These results line parallel with the findings of Akhtar et al. (2010, and 2015) who found that all existing $\mathrm{Bt}$ and non Bt-cotton varieties belonging to G. birsutum species are susceptible to CLCuD. Vulnerability to whitefly colonization also showed significantly varied response among tested $\mathrm{Bt}$ and non-Bt cotton varieties (Figure 1). However, the correlation between CL$\mathrm{CuD}$ symptoms severity and whitefly population levels was non-significant for all the tested varieties except for Bt114. Non Bt varieties (NIAB-Karishma and NIAB-846) showing minimum disease although it attracted maximum whiteflies as received by other tested varieties having high PDI. On the other hand Bt varieties Bt-114 showed better response against whiteflies and virus. Previous studies also proved that whitefly population levels do not correlate significantly with disease incidence (Hameed et al., 1994; Briddon et al., 2000; Akhtar et al., 2004).

\section{CONCLUSIONS}

From the above findings it is concluded that NIAB-Karishma was the most susceptible variety against whitefly and there is a constant threat of $\mathrm{CLCuV}$ on this genotype. Jassid was found to be the most damaging pest to all the varieties. Whereas, pink bollworm infestation was highest on Lalazar. Bt-114 showed better response against whiteflies and CLCuD. To minimize future losses in cotton, it is suggested that this variety could be used along with adaptation of management strategies in areas having severe problem of whitefly and CLCuD.

\section{ACKNOWLEDGEMENTS}

The authors acknowledges the services and inputs provided by NIAB farm branch. Moreover, the authors are very great ful for the provision of cotton seeds by NIBGE and PBGD, Faisalabad.

\section{CONFLICT OF INTEREST}

The authors declare that there is no conflict of interests whatsoever.

\section{AUTHORS CONTRIBUTION}

Muhammad Naveed and Rashid Ahmed Khan conceived the idea, design the experiment and wrote the manuscript. Khalid Pervaiz Akhtar recorded the CLCuD data. Mureed Hussain recorded the entomological data and analyzed the data.

\section{REFERENCES}

- Ahmad M, Arif MI, Ahmad Z, Denholm I (2001). Cotton whitefly (Bemesia tabaci) resistance to organophosphate and pyrethroid insecticides in Pakistan. Pest Manag. Sci. (58): 203-208. https://doi.org/10.1002/ps.440

- Akhtar KP, Hussain M, Khan AI, Haq MA, Iqbal MM (2004). Influence of plant age, whitefly population and cultivar resistance on infection of cotton plants by cotton leaf curl virus $(\mathrm{CLCuV})$ in Pakistan. Field Crops Res. (86):15-21. https://doi.org/10.1016/S0378-4290(03)00166-7

- Akhtar KP, Hussain M, Hassan M, Sarwar M, Sarwar N (2015). Evaluation of Bt-cotton genotypes for resistance to cotton leaf curl disease under high inoculum pressure in the field and using graft inoculation in glasshouse. Plant Pathol. J. (31): 132-139. https://doi.org/10.5423/PPJ. OA.01.2015.0014

- Akhtar KP, Haider S, Khan MKR, Ahmad M, Sarwar N, Murtaza MA, Aslam M (2010). Evaluation of Gossypium species for resistance to cotton leaf curl virus Burewala virus. Ann. Appl. Biol. (157): 135-147. https://doi.org/10.1111/ j.1744-7348.2010.00416.x

- Anonymous (2015). Economic survey of Pakistan. Ministry of 
Finance. Gov. of Pakistan. pp: 26.

- Arshad M, Suhail A (2010). Studying the sucking insect pest community in transgenic Bt cotton. Int. J. Agric. Biol. (12): 764-768.

- Bhat MG, Joshi AB, Singh M (1986). Relative loss of seed cotton yield by jassid and bollworms in some cotton genotype (Gossypiumbirsutum L.). Indian J. Entomol. (46): 169-173.

- Briddon RW, Mansoor S, Bedford ID, Pinner MS, Markham PG (2000). Clones of cotton leaf geminivirus induced symptoms typical of cotton leaf curl disease. Virus Genes. (20): 17-24. https://doi.org/10.1023/A:1008151921937

- Gould F (1998). Sustainability of transgenic insecticidal cultivars: integrating pest genetics and ecology. Annu. Rev. Entomol. (43): 701-726. https://doi.org/10.1146/annurev. ento.43.1.701

- Hameed S, Khalid S, Haq E, Hashmi AA (1994). Cotton leaf curl virus in Pakistan caused by a whitefly transmitted geminivirus. Plant Virol. Lab. NARC Islamabad Pak. Plant Dis. (78): 529. https://doi.org/10.1094/PD-78-0529H

- Jeyakumar P, Tanwar RK, Chand M, Singh A, Monga D, Bombawale OM (2008). Performance of Bt cotton against sucking pest. J. Biopest. (1): 223-225.

- Naqvi KM (1976). Crop protection to boost up cotton production. Proc. Cotton. Prod. Seminar, Organized by

ESSO Fert. Co. Ltd., Pak.119-125.

- Nelson MR, Nadeem A, Ahmad W, Orum TV (1998). Global assessment of cotton viral diseases. In Proc. Beltwide cotton Conf. San Diego, CA. 5-9 Jan., 1998. National cotton council. Am. Mamphis, Tn: 161-162.

- Tabashnik BE (1994). Evolution of resistance to Bacillus thuringiensis. Annu. Rev. Entomol. (39): 47-79. https://doi. org/10.1146/annurev.en.39.010194.000403

- Tabashnik BE, Wu K, Wu Y (2012). Early detection of fieldevolved resistance to Bt cotton in China: Cotton bollworm and pink bollworm. J. Inverteb. Pathol. (110): 301-306. https://doi.org/10.1016/j.jip.2012.04.008

- Wan P, Wu K, Huang M, Wu J (2004). Seasonal pattern of infestation by pink bollworm (Pictinophoragossypiella) (Saunders) in field plot of transgenic Bt cotton in the Yongtze river valley of China. Crop Protect. (23): 463-467. https://doi.org/10.1016/j.cropro.2003.09.017

-Wu KM, Guo YY (2005). The evolution of cotton pest management practices in china. Annu. Rev. Entomol. (50): 31-52. https://doi.org/10.1146/annurev. ento.50.071803.130349

- Zia K, Ashfaq M, Arif MJ, Sahi ST (2011). Effect of physiomorphic characters on population of whitefly Bemesia tabaci in transgenic cotton. Pakistan J. Agric. Sci. (48): 63-69. 